\title{
Amniotic fluid concentrations of dimeric inhibins, activin A and follistatin in pregnancy
}

\author{
S Muttukrishna, P Chamberlain, L W Evans ${ }^{1}$, J Asselin, N P Groome ${ }^{1}$ and W L Ledger \\ Nuffield Department of Obstetrics and Gynaecology, John Radcliffe Hospital, Headington, Oxford OX3 9DU, UK and ${ }^{1}$ School of Biological and \\ Molecular Sciences, Oxford Brookes University, Oxford OX3 OBP, UK \\ (Correspondence should be addressed to S Muttukrishna)
}

\begin{abstract}
Objective: The feto-placental unit is the major source of circulating concentrations of inhibin A and activin A in human pregnancy. The aim of this study was to measure the amniotic fluid concentrations of inhibin A, inhibin B, activin A and follistatin in pregnancies bearing male and female fetuses. Design and Method: Amniotic fluid samples collected by amniocentesis were stored at $-20^{\circ} \mathrm{C}$. Dimeric inhibins, 'total' activin A and 'total' follistatin were measured using specific two-site enzyme immunoassays. Samples were assayed blindly and the information on fetal sex was obtained from the cytogenetics laboratory.

Results: Data show that amniotic fluid concentrations of inhibin A, inhibin B and activin A gradually increase with gestation whilst concentrations of follistatin are similar between weeks 15 and 20 of pregnancy. Mean amniotic fluid levels of inhibin A and inhibin B at 16 and 17 weeks gestation and mean activin A levels at 15 and 16 weeks gestation are considerably lower in pregnancies with male $(n=24)$ compared with female $(n=28)$ fetuses. Levels of follistatin are not different in the male and female fetal pregnancies at any studied gestation.

Conclusions: The results indicate that amniotic fluid contains high concentrations of inhibins (A and B), activin $\mathrm{A}$ and follistatin in early pregnancy suggesting that these hormones are produced by the fetal membranes and may be involved in the development of the fetus.
\end{abstract}

European Journal of Endocrinology 140 420-424

\section{Introduction}

Inhibins are glycoprotein hormones consisting of two dissimilar subunits. Inhibin $A$ is an $\alpha-\beta_{\mathrm{A}}$ dimer and inhibin $\mathrm{B}$ is an $\alpha-\beta_{\mathrm{B}}$ dimer. Activins are homodimeric glycoprotein hormones. Activin $\mathrm{A}$ is a $\beta_{\mathrm{A}}-\beta_{\mathrm{A}}$ dimer, activin $\mathrm{AB}$ is a $\beta_{\mathrm{A}}-\beta_{\mathrm{B}}$ dimer and activin $\mathrm{B}$ is a $\beta_{\mathrm{B}}-\beta_{\mathrm{B}}$ dimer. Follistatin is a structurally distinct single chain glycoprotein hormone with functional similarity to inhibin. Within the last decade follistatin has also been identified as a high affinity activin binding protein (1).

Classically, inhibins and activins were isolated and purified based on their effect on pituitary folliclestimulating hormone (FSH) secretion. Inhibins inhibited pituitary FSH secretion and activins stimulated FSH secretion. Inhibins, activins and follistatins were initially purified and characterised from ovarian follicular fluid in different species. Extragonadal sources have also been identified for these proteins (2). Development of specific assays for inhibin A $(3,4)$, inhibin B (5), activin $A(6)$, activin $A B(7)$ and follistatin (8) has enabled us to measure the specific molecular form of dimeric protein.
Using these new specific assays, high concentrations of inhibin A (9) and activin A (10) have been measured throughout pregnancy. However, inhibin B concentrations in maternal circulation during pregnancy have been reported to be very low, with levels close to or at the detection limit of the assay $(11,12)$. Studies in early pregnancy support a feto-placental origin for inhibin A and activin A (13-15). Messenger RNA for inhibin $\alpha$ subunit has been identified in the syncytiotrophoblast and inhibin/activin $\beta_{\mathrm{A}}$ and $\beta_{\mathrm{B}}$ mRNAs have been identified in both cytotrophoblast and syncytiotrophoblast in the placenta (2). Immunocytochemical staining has also shown the presence of the $\alpha$ subunit, $\beta_{\mathrm{A}}$ subunit and the $\beta_{\mathrm{B}}$ subunit protein in syncytiotrophoblast $(16,17)$ and the decidua $(18)$.

Recently two studies have reported amniotic fluid levels of inhibin A and inhibin B in normal (19) and abnormal pregnancies affected with Down's syndrome (20). However, levels of activin A and follistatin have not been studied in the amniotic fluid in the second trimester. The aim of this study was to investigate the concentrations of inhibin A, inhibin B, activin A and follistatin in amniotic fluid of pregnancies bearing male and female fetuses in the second trimester. 


\section{Materials and methods}

\section{Amniotic fluids}

Amniotic fluid samples $(n=146)$ were collected at amniocentesis performed for clinical diagnostic reasons. Amniotic fluid was centrifuged to remove any fetal cells and the supernatant was frozen at $-20^{\circ} \mathrm{C}$ until assayed for inhibin A, inhibin B, activin A and follistatin. All samples analysed were from genetically normal fetal pregnancies. Samples were analysed blind and the information on fetal sex was subsequently obtained from the cytogenetics laboratory. The results of assays from female fetus bearing pregnancies and male fetus bearing pregnancies were analysed to study any difference in levels of inhibins, activin A and follistatin. For statistical analysis, samples were separated into male $(n=13, n=28, n=15, n=7, n=5)$ and female ( $n=12, n=24, n=24, n=10$ and $n=8)$ fetus bearing pregnancies at $15,16,17,18$ and 20 weeks respectively. Gestational age was determined by ultrasound and the date of the last menstrual period.

\section{Hormone assays}

Inhibin $\boldsymbol{A}$ Amniotic fluid concentrations of dimeric inhibin A were measured in duplicate $10 \mu \mathrm{l}$ aliquots as described elsewhere (4). The mean intra- and interassay coefficients of variation were $4.3 \%$ and $5.1 \%$ respectively. The minimum detection limit of the assay for human recombinant inhibin A (NIBSC, South Mimms, UK) was $2 \mathrm{pg} / \mathrm{ml}$.

Inhibin B Amniotic fluid concentrations of dimeric inhibin B were measured in $10 \mu \mathrm{l}$ duplicate aliquots using an enzyme immunoassay (EIA) as described in detail elsewhere (5). An in-house standard preparation (partially purified human follicular fluid) was standardised against human recombinant inhibin B (Genentech, San Francisco, CA, USA) and was used as the assay standard. The minimum detection limit of the assay for human recombinant inhibin B was $10 \mathrm{pg} / \mathrm{ml}$. The mean intra- and interassay coefficients of variation were $6.2 \%$ and $7.2 \%$ respectively.

Follistatin Amniotic fluid concentrations of 'total' follistatin (follistatin 288) were measured in duplicate as previously described (8). The minimum detection limit of the assay for human recombinant follistatin standard was $20 \mathrm{pg} / \mathrm{ml}$. The mean intra- and interassay coefficients of variation were $<10 \%$. The assay cross reacts $9.9 \%$ with follistatin 315 .

Activin A Amniotic fluid concentrations of 'total' activin A were measured using an EIA specific for 'total' activin A as described in detail elsewhere (6). The mean intra- and interassay coefficients of variation were $6.5 \%$ and $7.7 \%$ respectively. The minimum detection limit of the assay for human recombinant activin $\mathrm{A}$ (Genentech) was $50 \mathrm{pg} / \mathrm{ml}$.

\section{Statistical analysis}

Unpaired Student's t-tests were carried out to investigate the difference in amniotic fluid concentrations of the hormones between male and female fetus bearing pregnancies at a particular gestation. One-way analysis of variance with Bonferroni Dunn posthoc test was carried out to investigate the changes in levels across the gestations. Correlation analysis (Pearson correlation) was used to study the relationship between the hormones with increasing gestation time.

\section{Results}

Amniotic fluid levels of inhibin A increased with gestation from 15 to 18 weeks and then remained similar up to 20 weeks (Fig. 1a). Levels of inhibin A tended to be higher in female $(0.68 \pm 0.08 \mathrm{ng} / \mathrm{ml}$; $1.19 \pm 0.6 \mathrm{ng} / \mathrm{ml}$ respectively) than in male $(0.55 \pm$ $0.05 \mathrm{ng} / \mathrm{ml} ; 0.75 \pm 0.12 \mathrm{ng} / \mathrm{ml}$ respectively) bearing pregnancies at 16 and 17 weeks gestation, but this difference did not reach statistical significance (Fig. 1b and Table 1).

Inhibin B concentrations in the amniotic fluid increased progressively from 15 to 20 weeks $(P<$ 0.001; ANOVA; Fig. 2a). Although levels of inhibin B also appeared higher in the amniotic fluid from female fetus bearing pregnancies $(0.26 \pm 0.04 \mathrm{ng} / \mathrm{ml}, 0.42 \pm$ $0.06 \mathrm{ng} / \mathrm{ml}, 0.66 \pm 0.24 \mathrm{ng} / \mathrm{ml}$ and $0.6 \pm 0.17 \mathrm{ng} / \mathrm{ml}$
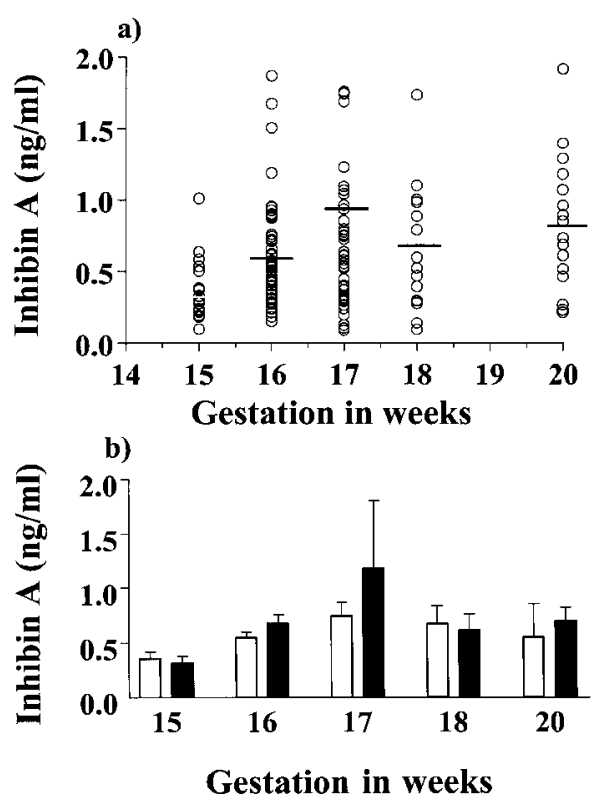

Figure 1 (a) Scatter plot of individual concentrations of amniotic fluid inhibin $A$ at different gestations. (b) Mean \pm S.E.M. concentrations of inhibin A in male (open bars) and female (solid bars) fetus bearing pregnancies. 
Table 1 Concentrations of inhibin A, inhibin B, activin A and follistatin in male and female bearing pregnancies from 15 to 20 weeks gestation. Results are means \pm S.E.M.

\begin{tabular}{|c|c|c|c|c|c|}
\hline & \multicolumn{5}{|c|}{ Weeks gestation } \\
\hline & 15 & 16 & 17 & 18 & 20 \\
\hline Inhibin A (ng/ml) & & & & & \\
\hline $\begin{array}{l}\text { Female } \\
\text { Male }\end{array}$ & $\begin{array}{l}0.32 \pm 0.06 \\
0.36 \pm 0.06\end{array}$ & $\begin{array}{l}0.68 \pm 0.08 \\
0.55 \pm 0.05\end{array}$ & $\begin{array}{l}1.19 \pm 0.6 \\
0.75 \pm 0.12\end{array}$ & $\begin{array}{l}0.68 \pm 0.08 \\
0.55 \pm 0.05\end{array}$ & $\begin{array}{l}0.71 \pm 0.12 \\
0.56 \pm 0.3\end{array}$ \\
\hline $\begin{array}{l}\text { Inhibin B (ng/ml) } \\
\text { Female } \\
\text { Male }\end{array}$ & $\begin{array}{l}0.09 \pm 0.02 \\
0.15 \pm 0.04\end{array}$ & $\begin{array}{r}0.26 \pm 0.04 \\
0.2 \pm 0.04\end{array}$ & $\begin{array}{l}0.42 \pm 0.06 \\
0.26 \pm 0.07\end{array}$ & $\begin{array}{l}0.66 \pm 0.24 \\
0.32 \pm 0.09\end{array}$ & $\begin{array}{r}0.6 \pm 0.17 \\
0.41 \pm 0.19\end{array}$ \\
\hline $\begin{array}{l}\text { Activin A }(\mathrm{ng} / \mathrm{ml}) \\
\text { Female } \\
\text { Male }\end{array}$ & $\begin{array}{r}5.17 \pm 0.62 \\
3.9 \pm 0.06\end{array}$ & $\begin{array}{c}5.8 \pm 0.8 \\
4.84 \pm 0.39\end{array}$ & $\begin{array}{r}4.5 \pm 0.48 \\
4.89 \pm 0.62\end{array}$ & $\begin{array}{r}5.8 \pm 0.8 \\
7.39 \pm 0.6\end{array}$ & $\begin{array}{r}8.9 \pm 1.7 \\
5.21 \pm 2.4\end{array}$ \\
\hline $\begin{array}{l}\text { Follistatin }(\mathrm{ng} / \mathrm{ml}) \\
\text { Female } \\
\text { Male }\end{array}$ & $\begin{array}{r}1.8 \pm 0.12 \\
1.63 \pm 0.16\end{array}$ & $\begin{array}{l}1.57 \pm 0.12 \\
1.93 \pm 0.15\end{array}$ & $\begin{array}{l}1.48 \pm 0.1 \\
1.62 \pm 0.18\end{array}$ & $\begin{array}{l}1.49 \pm 0.19 \\
1.57 \pm 0.6\end{array}$ & $\begin{array}{r}1.4 \pm 0.15 \\
1.36 \pm 0.52\end{array}$ \\
\hline
\end{tabular}

respectively) than from male fetus bearing pregnancies $(0.2 \pm 0.04 \mathrm{ng} / \mathrm{ml}, 0.26 \pm 0.07 \mathrm{ng} / \mathrm{ml}, 0.32 \pm 0.09 \mathrm{ng} /$ $\mathrm{ml}$ and $0.41 \pm 0.19 \mathrm{ng} / \mathrm{ml}$ respectively) from 16 to 20 weeks, the difference was not statistically significant (Fig. 2b and Table 1).

Total activin A levels also rose slightly from 15 to 20 weeks gestation (Fig. 3a) but with no statistical significance. Activin A levels also appeared to be higher in female fetus bearing pregnancies $(5.17 \pm 0.62 \mathrm{ng} / \mathrm{ml}, 5.81 \pm$ $0.81 \mathrm{ng} / \mathrm{ml}$ respectively) than in male fetus bearing pregnancies $(3.9 \pm 0.06 \mathrm{ng} / \mathrm{ml}, 4.84 \pm 0.39 \mathrm{ng} / \mathrm{ml})$ at 15 and 16 weeks gestation (Fig. $3 \mathrm{~b}$ and Table 1) but the difference was not statistically significant.

Follistatin levels did not alter between 15 and 20 weeks gestation (Fig. 4a). Levels of follistatin were also similar in male and female fetus bearing pregnancies (Fig. 4b and Table 1) at the studied gestations.

Correlation analysis showed that amniotic fluid concentrations of inhibin A and follistatin were not significantly correlated with any other parameters a)

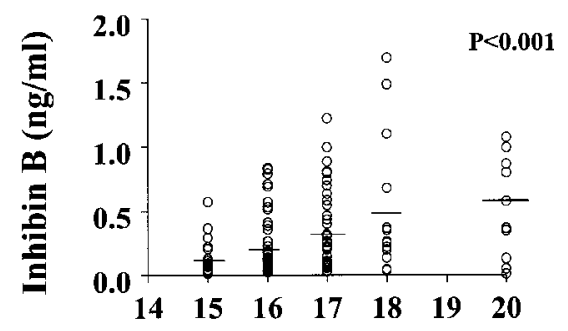

b)

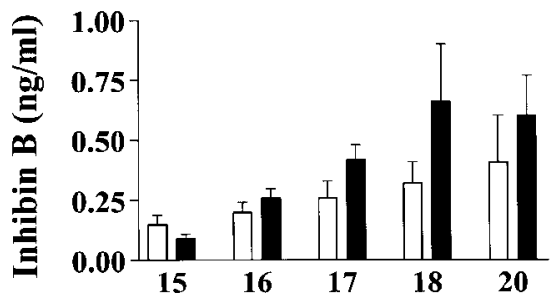

Gestation in weeks

Figure 2 (a) Scatter plot of individual concentrations of amniotic fluid inhibin $B$ at different gestations. (b) Mean \pm s.E.M. concentrations of inhibin $B$ in male (open bars) and female (solid bars) fetus bearing pregnancies. $P<0.001$ (ANOVA) - significant increase with gestation.

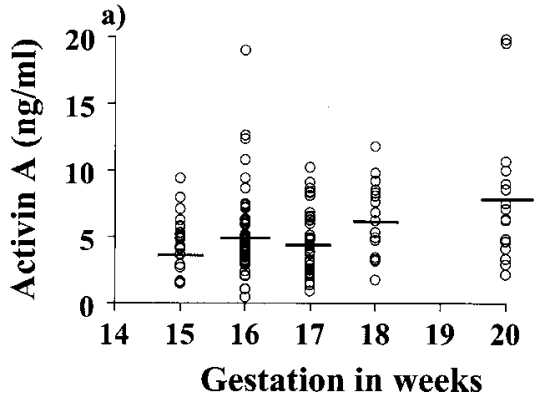

b)



Gestation in weeks

Figure 3 (a) Scatter plot of individual concentrations of amniotic fluid activin $A$ at different gestations. (b) Mean \pm S.E.M. concentrations of activin $A$ in male (open bars) and female (solid bars) fetus bearing pregnancies. 



Figure 4 (a) Scatter plot of individual concentrations of amniotic fluid follistatin at different gestations. (b) Mean \pm S.E.M. concentrations of follistatin in male (open bars) and female (solid bars) fetus bearing pregnancies.

measured. Inhibin B levels were significantly correlated with activin A levels $(r=0.2, P<0.02)$.

\section{Discussion}

We have investigated the amniotic fluid concentrations of inhibin A, inhibin B, activin A and follistatin from 15 to 20 weeks gestation and in male and female fetus bearing pregnancies. This is the first study to report activin $\mathrm{A}$ and follistatin levels in the amniotic fluid in the second trimester of male and female bearing pregnancies. Maternal serum concentrations of inhibin $A$ and activin A have been reported to be high in the circulation throughout pregnancy $(9,10)$. However, inhibin B levels are low and near the detection limit of the assay $(11,12)$. In pregnancy, the major source of inhibin $A$ and activin $A$ is the feto-placental unit (13-15). However, the feto-placental source of inhibins and activin $A$ in maternal serum could be different from the source of amniotic fluid inhibins and activin A because inhibin $\mathrm{B}$ is not detectable in maternal circulation but is present in high quantities in the amniotic fluid.

Studies have been carried out on the cellular localisation of inhibin/activin subunits using specific antibodies to the $\alpha, \beta_{\mathrm{A}}$ and $\beta_{\mathrm{B}}$ subunits in the placenta. In the first and second trimester placenta, positive staining for $\alpha$ and $\beta_{\mathrm{A}}$ subunits was clearly observed in the syncytial layer, with very faint staining for $\beta_{\mathrm{B}}$ subunits (16). The epithelial layer of the amnion showed an intense fluorescent staining for $\beta_{\mathrm{B}}$ subunit and positive signals were also observed for the $\alpha$ and $\beta_{\mathrm{A}}$ subunits $(21,22)$. Maternal decidual cells stained with both inhibin $\alpha$ and $\beta_{\mathrm{B}}$ antisera showed a similar localisation. Cells stained with $\beta_{\mathrm{A}}$ subunit were sparse and followed a distribution pattern different from that of cells stained with $\alpha$ or $\beta_{\mathrm{B}}$ antisera (18).

This study's data are consistent with other reports showing that high concentrations of inhibins $(19,20)$ and 'total' activin A (23) are present in the amniotic fluid. In our study, we have investigated the levels of inhibins ( $\mathrm{A}$ and $\mathrm{B}$ ), activin $\mathrm{A}$ and follistatin in the amniotic fluid of male and female bearing pregnancies.

The follistatin assay used in this study essentially detects follistatin 288 and cross reacts considerably with follistatin 315 (9.9\%). The amount of the different molecular forms of follistatin in the amniotic fluid is not known although follistatin 315 is reported to be the major follistatin form in human circulation (24). However, high concentrations $(1-2 \mathrm{ng} / \mathrm{ml})$ of follistatin 288 are present in amniotic fluid. This study shows that follistatin levels tend to decrease in amniotic fluid between 15 and 20 weeks gestation, in contrast to the pattern seen for inhibins and activin A. However, there is no significant correlation between follistatin and activin A or inhibins.

Measurements in peripheral serum collected from adult men have identified mainly inhibin B (25), activin A (6) and follistatin (8) with inhibin A levels close to the detection limit of the assay. In contrast, amniotic fluid contains high concentrations of inhibin A, inhibin $\mathrm{B}$, activin $\mathrm{A}$ and follistatin whether the fetus is male or female. However, it is very interesting that inhibin B levels are high in the amniotic fluid and hardly detectable in the maternal circulation indicating that the source of these proteins in the maternal circulation is different from the source in the amniotic fluid. It will be interesting to investigate the levels of these proteins in the uterine vein and compare it with maternal circulating levels.

High concentrations of inhibins, activin $A$ and follistatin in the amniotic fluid suggest a biological function for these proteins in this fetal compartment in pregnancy. Little is known about the physiological role of these proteins in pregnancy although the maternal circulating levels and amniotic fluid levels are higher in pregnancy compared with the menstrual cycle.

Activin-A is reported to play a role in early embryo development and mesoderm induction in other species. However, there are no reported studies on the effect of activin/inhibin on human embryo development (26).

In summary, amniotic fluid is a source of inhibin A, inhibin B, activin A and follistatin 288 and 315 in second trimester pregnancy. Levels of inhibin B progressively rise between 15 and 20 weeks gestation whereas inhibin A, activin A and follistatin levels do not change significantly. Levels of all proteins do not vary significantly between pregnancies bearing male and female fetuses. 


\section{Acknowledgements}

The authors thank the Cytogenetics Department at the Oxford Radcliffe Trust for the karyotype results, Genentech Inc. for the human recombinant activin A standards and the National Institute for Biological Standards for the recombinant inhibin A standards. S M acknowledges the Wellcome Trust for financial support.

\section{References}

1 Shimonaka M, Inouye S, Shimasaki S \& Ling N. Follistatin binds to both activin and inhibin through the common beta-subunit. Endocrinology 1991128 3313-3315.

2 Meunier H, Rivier C, Evans RM \& Vale W. Gonadal and extragonadal expression of inhibin $\alpha, \beta \mathrm{A}$ and $\beta \mathrm{B}$ subunits in various tissues predicts diverse functions. Proceedings of the National Academy of Sciences of the USA 198885 247-251.

3 Groome NP, Illingworth PJ, O'Brien M, Cooke I, Ganesan TS, Baird DT et al. Detection of dimeric inhibin throughout the human menstrual cycle by two-site enzyme immunoassay. Clinical Endocrinology 199440 717-723.

4 Muttukrishna S, Fowler PA, Groome NP, Mitchell GG, Robertson WR \& Knight PG. Serum concentrations of dimeric inhibin during the spontaneous human menstrual cycle and after treatment with exogenous gonadotrophin. Human Reproduction 19949 1634-1642.

5 Groome NP, Illingworth PJ, O’Brien M, Pai R, Rodger FE, Mather J et al. Measurement of dimeric inhibin-B throughout the human menstrual cycle. Journal of Clinical Endocrinology and Metabolism 199681 1401-1405.

6 Knight PG, Muttukrishna S \& Groome NP. Development and application of a two-site enzyme immunoassay for the determination of 'total' activin-A concentrations in serum and follicular fluid. Journal of Endocrinology 1996148 267-279.

7 Evans LW, Muttukrishna S, Knight PG \& Groome NP. Development, validation and application of a two-site enzyme-linked immunosorbent assay for activin-AB. Journal of Endocrinology $1997153221-230$

8 Evans LW, Muttukrishna S \& Groome N. Development, validation and application of an ultra sensitive two-site enzyme immunoassay for human follistatin. Journal of Endocrinology 1998156 275-282.

9 Muttukrishna S, George L, Fowler PA, Groome NP \& Knight PG. Measurement of serum concentrations of inhibin-A ( $\alpha-\beta$ A dimer during human pregnancy. Clinical Endocrinology 199542391 397.

10 Muttukrishna S, Fowler PA, George L, Groome NP \& Knight PG. Serum concentrations of 'total' activin A during the human menstrual cycle and pregnancy. Journal of Clinical Endocrinology and Metabolism 199681 3328-3334.

11 Illingworth PJ, Groome NP, Duncan WC, Grant V, Tovanabutra S, Baird DT et al. Measurement of circulating inhibin forms during the establishment of pregnancy. Journal of Clinical Endocrinology and Metabolism 199681 1471-1475.

12 Petraglia F, Luisi S, Benedetto C, Zonca M, Florio P, Casarosa E et al. Changes of dimeric inhibin B levels in maternal serum throughout healthy gestation and in women with gestational diseases. Journal of Clinical Endocrinology and Metabolism 199782 2991-2995.

13 Birdsall M, Ledger WL, Groome NP, Abdalla H \& Muttukrishna S. Inhibin A and activin A in the first trimester of human pregnancy. Journal of Clinical Endocrinology and Metabolism 199782 15571560.

14 Lockwood GM, Ledger WL, Barlow DH, Groome NP \& Muttukrishna S. Measurement of inhibin and activin in early human pregnancy: demonstration of feto-placental origin and role in prediction of early pregnancy outcome. Biology of Reproduction 199757 1490-1494.

15 Muttukrishna S, Child TJ, Groome NP \& Ledger WL. Source of circulating levels of inhibin A, pro alpha C-containing inhibins and activin A in early pregnancy. Human Reproduction 199712 1089-1093.

16 Minami S, Yamoto $M$ \& Nakano R. Immunohistochemical localization of inhibin/activin subunits in human placenta. Obstetrics and Gynecology 199280 410-414.

17 Petraglia F, Sawchenko P, Lim ATW, Rivier J \& Vale W. Localization, secretion, and action of inhibin in human placenta. Science 1987237 187-189.

18 Petraglia F, Calza L, Garuti GC, Abrate M, Giardino L, Genazzani A et al. Presence and synthesis of inhibin subunits in human decidua. Journal of Clinical Endocrinology and Metabolism 199071 487-492.

19 Wallace EM, Riley SC, Crossley JA, Ritoe SC, Horne A, Shade M et al. Dimeric inhibins in amniotic fluid, maternal serum, and fetal serum in human pregnancy. Journal of Clinical Endocrinology and Metabolism 199782 218-222.

20 Wallace EM, Crossley JA, Groome NP \& Aitken DA. Amniotic fluid inhibin-A in chromosomally normal and Down's syndrome pregnancies. Journal of Endocrinology 1997152 109-112.

21 Petraglia F, Anceschi MM, Calza L, Garuti GC, Fusaro P, Giardino I et al. Inhibin and activin in human fetal membranes: evidence for a local effect on prostaglandin release. Journal of Clinical Endocrinology and Metabolism 199377 542-548.

22 Vihko KK, Blauer M, Kujansuu E, Vilska S, Alback T, Tuimala et al. Activin B: detection by an immunoenzymometric assay in human serum during ovarian stimulation and late pregnancy. Human Reproduction 199813 841-846.

23 Petraglia F, Di-Blasio AM, Florio P, Gallo R, Genazzani AR, Woodruff TK et al. High levels of fetal membrane activin beta A and activin receptor IIB mRNAs and augmented concentrations of amniotic fluid activin A in term or preterm labor. Journal of Endocrinology 1997154 95-101.

24 Schneyer AL, Hall HA, Lambert-Messerlian, Wang OF, Sluss P \& Crowley WF. Follistatin activin complexes in human serum and follicular fluid differ immunologically and biochemically. Endocrinology 1996137 240-247.

25 Illingworth PJ, Groome NP, Byrd W, Rainey WE, McNeilly AS, Mather JP et al. Inhibin-B: a likely candidate for the physiologically important form of inhibin in men. Journal of Clinical Endocrinology and Metabolism 199681 1321-1325.

26 Fuukui A \& Asashima M. Control of cell differentiation and morphogenesis in amphibian development. International Journal of Developmental Biology 199438 257-266.

Received 6 November 1998

Accepted 26 January 1999 